\title{
Comparison of prepartum low-energy or high-energy diets with a 2-diet far-off and close-up strategy for multiparous and primiparous cows
}

\author{
B. F. Richards, ${ }^{1} \odot$ N. A. Janovick, ${ }^{1}$ K. M. Moyes, ${ }^{1} \odot$ D. E. Beever, ${ }^{2 *}$ and J. K. Drackley ${ }^{1} \dagger \odot$ \\ ${ }^{1}$ Department of Animal Sciences, University of Illinois, Urbana 61801 \\ ${ }^{2}$ Keenan Systems, Borris, County Carlow, Ireland R95 AY27
}

\begin{abstract}
Previous research demonstrated that nutrition during the far-off (early) dry period may be as important to transition success as nutrition during the close-up dry period. Our objectives were to determine if a lowenergy, high-fiber diet fed throughout the dry period improved metabolic status and production of dairy cows compared with a higher-energy diet or a 2-diet system, and to compare responses of cows and heifers to those diets. Holstein cows $(\mathrm{n}=25$ with 10 primiparous per treatment) were assigned to each of 3 diets at $60 \mathrm{~d}$ before expected calving. Treatment LO [40.5\% wheat straw; $5.6 \mathrm{MJ}$ of net energy for lactation $\left(\mathrm{NE}_{\mathrm{L}}\right) / \mathrm{kg}$ of $\left.\mathrm{DM}\right]$ was designed to meet but not exceed National Research Council recommendations for ad libitum intake from dry-off until calving. Treatment HI was a high-energy diet (6.7 MJ of $\mathrm{NE}_{\mathrm{L}} / \mathrm{kg}$ of $\left.\mathrm{DM}\right)$ fed for ad libitum intake from dry-off until calving. For the $\mathrm{LO}+\mathrm{HI}$ treatment, the $\mathrm{LO}$ diet was fed ad libitum from dry-off until $21 \mathrm{~d}$ before expected calving, followed by the HI diet until parturition. After parturition all cows were fed a lactation diet $\left(7.0 \mathrm{MJ}\right.$ of $\mathrm{NE}_{\mathrm{L}} / \mathrm{kg}$ of $\mathrm{DM}$ ) through $63 \mathrm{~d}$ postpartum. Dry matter intake and body weight were greater for HI cows prepartum, but not postpartum. When $\mathrm{LO}+\mathrm{HI}$ cows were switched to the HI diet, their dry matter intake increased to match that of HI cows. Cows fed HI had greater gain of body condition before calving but lost more postpartum. Energy balance postpartum was higher for LO cows than for HI cows. Milk production, protein content, and protein yield did not differ among diets. Milk fat content and yield were highest for $\mathrm{HI}$ cows, lowest for LO, and intermediate for $\mathrm{LO}+\mathrm{HI}$ cows. The $\mathrm{HI}$ cows had lower serum nonesterified fatty acids prepartum than either $\mathrm{LO}$ or $\mathrm{LO}+\mathrm{HI}$, but greater concentrations postpartum.
\end{abstract}

Received March 27, 2020.

Accepted June 2, 2020.

*Deceased.

†Corresponding author: drackley@illinois.edu
Serum $\beta$-hydroxybutyrate did not differ prepartum, but was greater for $\mathrm{HI}$ than for $\mathrm{LO}$ or $\mathrm{LO}+\mathrm{HI}$ postpartum. Serum glucose and insulin were lower for LO than $\mathrm{HI}$ and $\mathrm{LO}+\mathrm{HI}$ prepartum; insulin was lower for $\mathrm{LO}$ and $\mathrm{HI}$ than for $\mathrm{LO}+\mathrm{HI}$ postpartum. The LO cows had lower liver total lipid concentration postpartum than the $\mathrm{HI}$ cows and $\mathrm{LO}+\mathrm{HI}$ cows. Primiparous cows generally responded to diets the same as multiparous cows. The LO $+\mathrm{HI}$ feeding strategy provided no benefit over the LO diet. Moreover, the high-energy diet, even when fed for only $19 \mathrm{~d}$ before calving in the LO+HI group, resulted in increased serum $\beta$-hydroxybutyrate and liver total lipid concentrations compared with LO. Key words: dry period, transition, production, metabolism

\section{INTRODUCTION}

Controlled feeding of cows during the dry period affects periparturient health, postcalving DMI, and lactation performance (Beever, 2006; Janovick et al., 2011). Dann et al. (2006) found that nutrition during the far-off dry period was more important than nutrition during the close-up dry period for transition success; DMI and energy balance increased, and serum BHB and nonesterified fatty acids (NEFA) decreased when diets were fed to meet NRC (2001) guidelines during the early dry period (far-off period) compared with overfeeding.

Janovick and Drackley (2010) found that a high-straw diet (32\% wheat straw; $9.08 \mathrm{MJ}$ of $\mathrm{ME} / \mathrm{kg}$ of $\mathrm{DM}$ and $142 \mathrm{~g}$ of $\mathrm{CP} / \mathrm{kg}$ of $\mathrm{DM})$ fed during the entire dry period resulted in DMI being maintained more constant to calving, less lipid accumulation in the liver, and lower blood ketone bodies than cows fed a higher-energy diet for ad libitum intake (11.21 MJ of $\mathrm{ME} / \mathrm{kg}$ of $\mathrm{DM}$ and $150 \mathrm{~g}$ of $\mathrm{CP} / \mathrm{kg}$ of $\mathrm{DM})$. These effects were similar to when prepartum DMI was limited by feed restriction (Dann et al., 2006; Douglas et al., 2006; Janovick and Drackley, 2010). Restricting the amount of feed offered to cows is difficult in group housing systems. Aggressive cows will have ad libitum intake, whereas more timid 
cows may have severely restricted intake. Including straw or other bulky forage in a TMR provides a way for feeding for ad libitum DMI while still controlling energy intake (Beever, 2006; Dann et al., 2006).

Many farmers continue to use a "steam-up" or closeup diet of greater nutrient density before calving based on recommendations from nutritionists. Surprisingly little research evidence exists, however, to support this practice (Drackley and Dann, 2008; Mann et al., 2015). Whether a close-up diet would provide benefits to cows fed on high-bulk diets during the early dry period also is not clear (Dann et al., 2006). Single-diet, single group dry cow programs have merit for small- to medium-size farms that have difficulties creating multiple pens of cows. Moreover, many farms commingle first-calving heifers with older cows in such management schemes, but little research is available to assess the nutritional outcomes of this practice. Heifers may respond differently or in different magnitude to nutritional manipulations compared with older cows (Vandehaar et al., 1999).

The objectives of our study were to (1) compare metabolic status and productivity of cows fed a controlled-energy, high-fiber diet throughout the entire dry period with cows fed a 2-diet dry cow system (controlled-energy far-off diet and higher-energy closeup diet), and (2) compare responses of second lactation and older cows with those of first-calving heifers. A negative control group also was included in which cows and heifers were fed the higher-energy close-up diet throughout the entire dry period. Our hypothesis was that the 1-diet group with energy intake controlled to near requirements would have less lipid mobilization and greater milk production than the 2-diet group, and that performance and health for both would exceed that of the 1-diet overfed group.

\section{MATERIALS AND METHODS}

\section{Cows, Dietary Treatments, and Management}

Thirty-one first-calving heifers and 48 second or greater lactation Holstein cows were randomly assigned on the basis of expected calving date to 1 of 3 prepartum dietary strategies. Cows were dried off at approximately $60 \mathrm{~d}$ before expected calving and were started on the experimental diets immediately after dry-off. Some cows were already dry because of long calving intervals and were started on diets at approximately 60 $\mathrm{d}$ prepartum; the number of these cows was balanced across all diets. First-parity heifers were moved to the experimental barn at the same time and were housed and fed together with the older cows for $60 \mathrm{~d}$ before expected calving.
Diet composition is presented in Table 1 and nutrient composition in Table 2 . The first dietary treatment was a controlled-energy, high-fiber diet (1 diet, low energy; LO) designed to meet, but not exceed, NRC (2001) requirements [formulated to $5.6 \mathrm{MJ}(1.35 \mathrm{Mcal})$ of $\mathrm{NE}_{\mathrm{L}} / \mathrm{kg}$ of $\mathrm{DM}$ and $11.9 \% \mathrm{CP}, \mathrm{DM}$ basis] when fed for ad libitum intake from dry-off until calving. This diet included wheat straw ( $40.5 \%$ of the DM) chopped directly into the TMR in a horizontal paddle mixer with knives (Keenan Klassik 140 mixer wagon, Keenan Systems, Borris, Ireland). Cows on the second treatment (1 diet, high energy; HI) were fed a high-energy diet [formulated to $6.7 \mathrm{MJ}(1.61 \mathrm{Mcal})$ of $\mathrm{NE}_{\mathrm{L}} / \mathrm{kg}$ of $\mathrm{DM}$ and $12.8 \%$ CP, DM basis; Tables 1 and 2] for ad libitum intake from dry-off until calving. The third treatment (2 diets; $\mathbf{L O}+\mathbf{H I}$ ) represented a typical 2-phase system in which the LO diet was fed for ad libitum intake from dry-off until $21 \mathrm{~d}$ prepartum, followed by feeding the HI diet until calving. We used a "partial DCAD" approach for all cows and heifers in which magnesium chloride and magnesium sulfate were added but we did not attempt to reach a negative dietary cation-anion difference (DCAD). At parturition all cows were fed a common lactation diet [formulated to $7.0 \mathrm{MJ}$ (1.67 Mcal) of $\mathrm{NE}_{\mathrm{L}} / \mathrm{kg}$ of $\mathrm{DM}$ and $17.5 \% \mathrm{CP}$; Tables 1 and 2]. A small amount (approximately $2 \mathrm{~kg}$ ) of long-stem alfalfa hay was offered to all cows as a top-dress to the lactation TMR for $10 \mathrm{~d}$ following parturition. Measurements were made through $63 \mathrm{~d}$ postpartum.

Multiparous cows assigned to each dietary group averaged 2.5, 3.0, and 3.1 parities for LO, HI, and $\mathrm{LO}+\mathrm{HI}$, respectively, with the mode being 2 parities for each group. Previous 305-d mature equivalent milk production did not differ among treatments and averaged $12,748,13,150$, and $13,693 \mathrm{~kg}$ for LO, HI, and $\mathrm{LO}+\mathrm{HI}$, respectively. The average pretreatment BCS was $3.1,3.2$, and 3.1 for the 3 groups.

Cows were housed prepartum in a freestall barn equipped with Calan gates (American Calan, Northwood, $\mathrm{NH}$ ) allowing for daily measurements of individual feed intake (feed offered minus feed refused, including top-dressed hay). Cows were moved into box stalls adjacent to the freestall pens when parturition was imminent. Cows were housed postpartum in a tiestall barn, bedded on chopped straw over rubber mats, and fed in concrete mangers.

Calving difficulty was scored on a scale of 1 to 5, where a score of 1 was assigned when a cow calved between observations without showing signs of parturition, a score of 2 was assigned when a cow showed signs of parturition and calved without assistance in $<6 \mathrm{~h}$ from first observation, a score of 3 was assigned when a cow was observed for $6 \mathrm{~h}$ and the calving progressed naturally without assistance, a score of 4 was assigned 
Table 1. Ingredient composition of diets (\% of total DM)

\begin{tabular}{|c|c|c|c|}
\hline Ingredient & Low $^{1}$ & High $^{1}$ & Lactation \\
\hline Wheat straw & 40.46 & 0.00 & 0.00 \\
\hline Alfalfa hay, mid-maturity & 3.24 & 6.00 & 3.50 \\
\hline Alfalfa silage, mid-maturity & 9.70 & 17.92 & 12.50 \\
\hline Corn silage & 28.32 & 49.88 & 34.00 \\
\hline Whole cottonseed & 0.00 & 4.99 & 9.00 \\
\hline Ground-shelled corn & 3.46 & 13.83 & 21.50 \\
\hline Soybean meal $48 \%$ & 11.33 & 4.29 & 2.50 \\
\hline SoyPlus $^{2}$ & 0.00 & 0.00 & 8.50 \\
\hline Soy hulls & 0.00 & 0.00 & 5.00 \\
\hline Blood meal & 0.00 & 0.00 & 1.00 \\
\hline Liquid fat & 0.00 & 0.00 & 0.25 \\
\hline Urea & 0.24 & 0.19 & 0.00 \\
\hline Dicalcium phosphate & 0.32 & 0.00 & 0.20 \\
\hline Limestone & 0.65 & 0.62 & 0.55 \\
\hline Magnesium oxide & 0.51 & 0.43 & 0.15 \\
\hline Magnesium sulfate & 0.69 & 0.62 & 0.00 \\
\hline Magnesium chloride & 0.40 & 0.55 & 0.00 \\
\hline Sodium sulfate & 0.00 & 0.00 & 0.10 \\
\hline Sodium bicarbonate & 0.00 & 0.00 & 0.75 \\
\hline Mineral and vitamin premix ${ }^{3}$ & 0.19 & 0.18 & 0.20 \\
\hline Salt (plain) & 0.20 & 0.23 & 0.20 \\
\hline Vitamin $\mathrm{A}^{4}$ & 0.01 & 0.01 & 0.00 \\
\hline Vitamin $D^{5}$ & 0.01 & 0.01 & 0.00 \\
\hline Vitamin $\mathrm{E}^{6}$ & 0.26 & 0.24 & 0.10 \\
\hline
\end{tabular}

${ }^{1}$ Low $=1$ diet, low energy; high = 1 diet, high energy.

${ }^{2}$ Landus Cooperative, Ralston, IA.

${ }^{3}$ Contained $5 \% \mathrm{Mg}, 10 \% \mathrm{~S}, 7.5 \% \mathrm{~K}, 2.0 \% \mathrm{Fe}, 3.0 \% \mathrm{Zn}, 3.0 \% \mathrm{Mn}, 5,000$ $\mathrm{mg} / \mathrm{kg}$ of Cu, $250 \mathrm{mg} / \mathrm{kg}$ of I, $40 \mathrm{mg} / \mathrm{kg}$ of Co, $150 \mathrm{mg} / \mathrm{kg}$ of Se, 2,200 $\mathrm{kIU} / \mathrm{kg}$ of vitamin $\mathrm{A}, 660 \mathrm{kIU} / \mathrm{kg}$ of vitamin $\mathrm{D}_{3}$, and $7,700 \mathrm{IU} / \mathrm{kg}$ of vitamin E.

${ }^{4}$ Contained 30,000 kIU/kg.

${ }^{5}$ Contained 5,009 kIU/kg.

${ }^{6}$ Contained 44,000 IU $/ \mathrm{kg}$.

when the calving lasted $>6 \mathrm{~h}$ and the cow required intervention without the use of mechanical assistance for calving, and a score of 5 was when the cow required intervention with the use of mechanical extraction because of the position or size of the calf. The first milking of colostrum was measured and recorded. Colostral $\operatorname{IgG}$ was estimated using a colostrometer.

\section{DMI and Feed Analyses}

Daily DMI was measured from assignment to diets (approximately $60 \mathrm{~d}$ prepartum) through $63 \mathrm{~d}$ postpartum. Dry matter content of individual feed ingredients was determined weekly and rations were adjusted accordingly to maintain DM ratios of ingredients in the TMR. Weekly samples of ingredients and TMR were frozen at $-20^{\circ} \mathrm{C}$ and then composited monthly for analysis of DM, CP, NDF, ADF, starch, Ca, P, K, $\mathrm{Cl}$, and $\mathrm{Mg}$ by standard wet chemistry techniques at a commercial laboratory (Dairy One, Ithaca, NY; Table $2)$. Estimated $\mathrm{NE}_{\mathrm{L}}$ values were assigned by Dairy One using NRC (2001) assumptions and equations. Particle
Table 2. Analyzed composition of $\operatorname{diets}^{1}$

\begin{tabular}{lccc}
\hline & \multicolumn{3}{c}{ Diet $^{2}$} \\
\cline { 2 - 4 } Component & Low & High & Lactation \\
\hline DM, \% of fresh weight & 52.4 & 48.4 & 56.2 \\
CP, \% of DM & 12.0 & 14.4 & 16.9 \\
NDF, \% of DM & 53.9 & 37.2 & 35.1 \\
ADF, \% of DM & 37.5 & 25.4 & 23.5 \\
NFC, $\%$ of DM & 24.6 & 41.9 & 40.4 \\
Starch, \% of DM & 12.4 & 27.2 & 25.1 \\
NE ${ }^{3}$ MJ/kg of DM & 5.61 & 6.74 & 6.99 \\
ME, MJ/kg of DM & 9.04 & 10.62 & 11.00 \\
Ca, \% of DM & 0.64 & 0.67 & 0.72 \\
P, \% of DM & 0.25 & 0.31 & 0.40 \\
Mg, \% of DM & 0.46 & 0.55 & 0.30 \\
K, \% of DM & 1.57 & 1.41 & 1.37 \\
Na, \% of DM & 0.08 & 0.11 & 0.32 \\
Cl, \% of DM & 0.62 & 0.56 & 0.32 \\
S, \% of DM & 0.25 & 0.22 & 0.21 \\
DCAD, ${ }^{5}$ mEq/100 g & 10.6 & 11.4 & 35.9 \\
TMR particle size & & & \\
Top & $20 \pm 8$ & $4 \pm 2$ & $7 \pm 3$ \\
Middle & $36 \pm 4$ & $46 \pm 6$ & $41 \pm 3$ \\
Bottom & $45 \pm 7$ & $50 \pm 7$ & $52 \pm 4$ \\
\hline
\end{tabular}

${ }^{1}$ Mean analyses of 9 monthly composite samples of TMR.

${ }^{2}$ Low $=1$ diet, low energy; high $=1$ diet, high energy.

${ }^{3}$ Calculated using NRC (2001) model.

${ }^{4}$ Analysis of one composite sample of individual ingredients.

${ }^{5}$ Dietary cation-anion difference calculated as $(\mathrm{Na}+\mathrm{K})-(\mathrm{Cl}+\mathrm{S})$.

${ }^{6}$ Mean $( \pm \mathrm{SD})$ particle size determined on each screen of the Penn State Particle Separator, expressed as the percentage of total weight on each screen.

size distribution was determined weekly for each of the TMR samples using a Penn State Particle Separator with 2 screens (19 and $8 \mathrm{~mm}$ ) and a pan (Table 2).

\section{Milk Production and Composition}

Cows were milked twice daily and milk yields were recorded. Consecutive evening and morning milk samples were taken weekly starting at $\geq 6$ through 63 DIM. Pooled milk samples were prepared in proportion to milk yield at each milking, preserved (800 Broad Spectrum Microtabs II; D \& F Control Systems Inc., San Ramon, CA), and analyzed for contents of fat, protein, lactose, SNF, urea N, and SCC using mid-infrared techniques (Dairy Lab Services, Dubuque, IA).

\section{Energy Balance, BW, and BCS}

Pre- and postpartum energy balance was calculated using equations from the NRC (2001). Intake of $\mathrm{NE}_{\mathrm{L}}$ was determined using daily DMI multiplied by $\mathrm{NE}_{\mathrm{L}}$ density in the diet. Maintenance $\mathrm{NE}_{\mathrm{L}}$ was calculated as $\mathrm{BW}^{0.75} \times 0.080$. Pregnancy requirements for $\mathrm{NE}_{\mathrm{L}}$ were calculated as $[(0.00318 \times$ day of gestation -0.0352$) \times$ 
(calf birth weight/45)]/0.218. Requirements of $\mathrm{NE}_{\mathrm{L}}$ for milk production were calculated as $(0.0929 \times$ fat, $\%)+$ $(0.0547 \times$ protein, $\%)+(0.0395 \times$ lactose, $\%)$. For primiparous cows, an additional $2.69 \mathrm{Mcal} / \mathrm{d}$ was added for retained energy for growth (i.e., $\mathrm{NE}_{\mathrm{G}}$ ) required during pregnancy as calculated previously for primiparous cows at the University of Illinois Dairy Research Unit (Janovick and Drackley, 2010).

Body weight was measured weekly for each cow at the same time after the morning milking and before feeding. A BCS (scale $1=$ thin to $5=$ obese, with quarter-point increments) was assigned to each cow weekly by 3 people independently and the median score was used for statistical analysis.

\section{Blood and Liver Sampling and Analyses}

Blood samples were obtained from the coccygeal vein or artery at $0600 \mathrm{~h}$ prepartum and $0700 \mathrm{~h}$ postpartum (after feed refusals were removed and before the morning feeding) weekly from 60 to $20 \mathrm{~d}$ before expected calving, twice weekly from 20 to $10 \mathrm{~d}$ before expected calving, 3 times weekly from $10 \mathrm{~d}$ before expected calving to $10 \mathrm{~d}$ postpartum, twice weekly from 10 to $20 \mathrm{~d}$ postpartum, and weekly from 20 to $63 \mathrm{~d}$ postpartum. Blood was collected into evacuated serum separator tubes containing clot activator (Becton Dickenson Vacutainer Systems, Franklin Lakes, NJ). Serum tubes were allowed to remain at ambient temperature for 30 min before separation. All tubes were centrifuged at $1,300 \times g$ for $15 \mathrm{~min}$ at room temperature to obtain serum, which then was divided into several aliquots that were stored at $-20^{\circ} \mathrm{C}$ until analysis.

Insulin in serum was measured using a radioimmunoassay kit (Coat-a-Count Insulin kit, Diagnostic Products Corporation, Los Angeles, CA) as modified by Studer et al. (1993). Concentrations of albumin (Doumas et al., 1971; Albumin Plus kit, Roche Diagnostics Corp., Indianapolis, IN), glucose (Peterson and Young, 1968; glucose/HK kit, Roche Diagnostics Corp.), NEFA (Johnson and Peters, 1993), and BHB (Williamson and Mellanby, 1974; BHB kit number 310-A, Sigma Chemical Co., St. Louis, MO) were measured in serum using an autoanalyzer (University of Illinois Clinical Pathology Laboratory, Urbana, IL). For determination of albumin, glucose, NEFA, and BHB concentrations, all available time points corresponding to planned sample days were used. Only blood samples taken at d $-14,1$, $3,5,9,30$, and 60 were analyzed for insulin. These time points corresponded approximately with liver biopsy days, parturition, and completion of the experiment.

Liver was sampled via puncture biopsy (Hughes, 1962) from cows under local anesthesia at $0700 \mathrm{~h}$ on $\mathrm{d}-14,10$, and 30 relative to parturition. Liver tissue was frozen immediately in liquid $\mathrm{N}$ and later analyzed for concentrations of total lipid (Hara and Radin, 1978) and triacylglycerol (Fletcher, 1968; Foster and Dunn, 1973).

\section{Health}

The incidence of health problems was recorded and summarized. All cows clinically diagnosed with ketosis were verified by serum BHB concentrations greater than $1.4 \mathrm{~m} M$. Other nonclinical cases of ketosis are reported based on serum BHB concentrations greater than $1.4 \mathrm{~m} M$.

\section{Statistical Analyses}

Weekly means of daily measurements for DMI and milk yield were calculated for statistical analysis. To avoid problems with fitting covariance structure, preand postpartum data were analyzed separately, with far-off and close-up prepartum data also analyzed separately. Data were analyzed as a randomized design using the MIXED procedure of SAS (Hatcher and Stepanski, 1994) with the following model:

$$
\begin{gathered}
\mathrm{y}_{\mathrm{ijkl}}=\mu \\
+\mathrm{W}_{\mathrm{i}}+\mathrm{P}_{\mathrm{j}}+\mathrm{WP}_{\mathrm{ij}}+\mathrm{D}_{\mathrm{k}}+\mathrm{WD}_{\mathrm{ik}} \\
+\mathrm{PD}_{\mathrm{jk}}+\mathrm{WPD}_{\mathrm{ijk}}+\mathrm{C}_{(\mathrm{ijk}) \mathrm{l}},
\end{gathered}
$$

where $\mathrm{y}_{\mathrm{ijkl}}=$ an observation from the ith time relative to calving, jth parity, kth diet, and lth cow; $\mu=$ the grand mean; $\mathrm{W}_{\mathrm{i}}=$ effect of the ith week or day; $\mathrm{P}_{\mathrm{j}}=$ effect of the jth parity; $\mathrm{WP}_{\mathrm{ij}}=$ effect of the time by parity interaction; $\mathrm{D}_{\mathrm{k}}=$ effect of the kth diet; $\mathrm{WD}_{\mathrm{ik}}=$ effect of the time by diet interaction; $\mathrm{PD}_{\mathrm{jk}}=$ effect of the parity by diet interaction; $\mathrm{WPD}_{\mathrm{ijk}}=$ effect of the time by parity by diet interaction; and $\mathrm{C}_{(\mathrm{ijk}) 1}=$ random experimental error from the lth cow nested within the ith time, jth parity, and kth diet. The REPEATED statement was used for variables measured over time (BW, BCS, DMI, milk yield, milk components, blood components, and liver composition). Degrees of freedom were estimated by using the Satterthwaite option in the model statement. Significance was declared when $P<0.05$ and tendencies or trends were declared at 0.05 $<P \leq 0.10$. When the diet effect was significant, least squares means were separated using the PDIFF option.

\section{RESULTS}

Median days dry for multiparous cows was 60,58 , and 61 for $\mathrm{LO}, \mathrm{HI}$, and $\mathrm{LO}+\mathrm{HI}$ groups, with ranges of 
36 to $170 \mathrm{~d}, 45$ to $114 \mathrm{~d}$, and 55 to $155 \mathrm{~d}$, respectively. The mean \pm standard deviation days on experimental diets before calving was $56 \pm 7,56 \pm 10$, and $57 \pm 8 \mathrm{~d}$ for $\mathrm{LO}, \mathrm{HI}$, and $\mathrm{LO}+\mathrm{HI}$, respectively. Cows and heifers in the $\mathrm{LO}+\mathrm{HI}$ group received the $\mathrm{LO}$ diet for $36 \pm 7 \mathrm{~d}$ and the HI diet for a mean of $19 \pm 6 \mathrm{~d}$ (mean $\pm \mathrm{SD}$ ).

A total of 10 cows originally assigned to diets were removed from the experiment before calving (4 multiparous and 3 primiparous cows not pregnant, aborted, or calved too early) or their data were removed from the prepartum data set (3 multiparous cows, did not adapt to Calan feed gates). Seven of these cows were replaced. The total number of cows in the final prepartum data set, therefore, was 23 for LO (13 cows and 10 heifers), 26 for $\mathrm{HI}$ ( 15 cows and 11 heifers), and 26 for $\mathrm{LO}+\mathrm{HI}$ (16 cows and 10 heifers). Four cows (3 multiparous and 1 primiparous) were removed at or after calving due to death or trauma, but prepartum data for these cows were retained in the data set. A total of 3 multiparous cows had partial data postpartum that were included in the data set, before these cows died or were removed as downer cows. The total number of cows in the final postpartum data set was 23 for LO (13 cows and 10 heifers), 24 for HI (14 cows and 10 heifers), and 24 for $\mathrm{LO}+\mathrm{HI}$ (14 cows and 10 heifers).

\section{Intakes, Energy Balance, BW, and BCS}

During the far-off period, DMI expressed both as kilograms per day and percentage of BW $(P<0.01)$, as well as intakes of $\mathrm{CP}$ and $\mathrm{NE}_{\mathrm{M}}(P<0.01)$, were greater for $\mathrm{HI}$ cows than for $\mathrm{LO}$ or $\mathrm{LO}+\mathrm{HI}$ cows (Table 3). Mean intakes were similar for $\mathrm{LO}$ and $\mathrm{LO}+\mathrm{HI}$. The DMI for HI cows was high during the middle of the far-off dry period but then began to decrease (diet $x$ week, $P<0.01$; Figure 1), whereas DMI for LO and $\mathrm{LO}+\mathrm{HI}$ was more constant. Heifers and cows generally responded similarly to diets (Table 3 ). The parity by diet interaction was not significant $(P=0.33)$ for DMI as a percentage of BW (Table 3). Diet by parity interactions were significant for DMI, CP intake, $\mathrm{NE}_{\mathrm{M}}$ intake, and energy balance as a percentage of requirement, which occurred because the differences between LO and HI diets were greater for multiparous cows than for primiparous cows (data not shown). Differences in intake resulted in similar patterns among diets for energy balance, expressed either as megajoules per day or percentage of requirements (Table 3, Figure $2 \mathrm{~A})$. During the far-off period, HI cows consumed $51 \%$ more energy than their requirement, whereas LO and LO $+\mathrm{HI}$ cows consumed $3.8 \%$ and $12.1 \%$ less than their requirements $(P<0.01$; Table 3 , Figure $2 \mathrm{~A})$.
During the far-off period, the greater DMI and $\mathrm{NE}_{\mathrm{M}}$ intake for $\mathrm{HI}$ cows resulted in the $\mathrm{HI}$ cows having greater mean BCS $(P<0.01)$ than either $\mathrm{LO}$ or $\mathrm{LO}+\mathrm{HI}$ cows (Table 3). Mean BCS was not affected by interactions of parity with week or diet. Mean BW did not differ significantly among diets, but the tendency $(P=0.06)$ for a diet by week interaction is illustrated in Figure 2B. The parity by diet interaction was not significant.

The DMI decreased during the close-up period, with differences among diets narrowing (diet $\times$ week, $P<$ 0.08; Figure 1). When $\mathrm{LO}+\mathrm{HI}$ cows were switched to the same diet as the HI cows at 3 wk before expected calving, their DMI increased to the same as HI cows and then followed them down at the same rate until calving (Figures 1 and 2). Intakes of $\mathrm{CP}$ and $\mathrm{NE}_{\mathrm{M}}$ followed the same pattern as DMI.

Energy balance was greater for cows fed $\mathrm{HI}$ and $\mathrm{LO}+\mathrm{HI}$ than for those fed LO during the close-up period (Table 3). Cows fed HI consumed on average $14.6 \%$ more energy than requirements during the week before parturition while LO+HI cows consumed $10.9 \%$ more than requirements; LO cows consumed 12.2\% less than requirements. Parity by diet interactions for energy balance were not significant. As in the far-off period, $\mathrm{BCS}$ was greater for $\mathrm{HI}$, with $\mathrm{LO}$ and $\mathrm{LO}+\mathrm{HI}$ not different from each other $(P<0.01)$. Mean BW did not differ among diets (Table 3 ).

Postpartum DMI did not differ $(P=0.65)$ among diets (Table 3). In contrast to what was observed prepartum, the HI cows had the most negative energy balance and $\mathrm{LO}$ cows the least negative; cows fed $\mathrm{LO}+\mathrm{HI}$ were intermediate $(P<0.01)$. Mean BCS followed the same trend $(P=0.06)$ among diets as energy balance, with HI cows losing BCS more rapidly than LO or $\mathrm{LO}+\mathrm{HI}$ cows (diet by week, $P<0.01$; Figure $2 \mathrm{C}$ ). No differences among diets or interactions were observed for postpartum BW.

\section{Calving Data}

The number of cows that calved with twins for LO, $\mathrm{HI}$, and $\mathrm{LO}+\mathrm{HI}$ groups was 3,1 , and 4, respectively. Mean calf birth BW did not differ among diets, and no difference was observed among diets in calving difficulty score (Table 4). Colostral IgG concentration did not differ among diets, and limited measurements of colostrum volume also indicated no differences (Table 4).

\section{Milk Yield and Composition}

Milk yield was not different among diets (Table 5) and the diet by parity interaction was not significant $(P$ 
Richards et al.: 1-DIET VERSUS 2-DIET SYSTEMS FOR DRY COWS

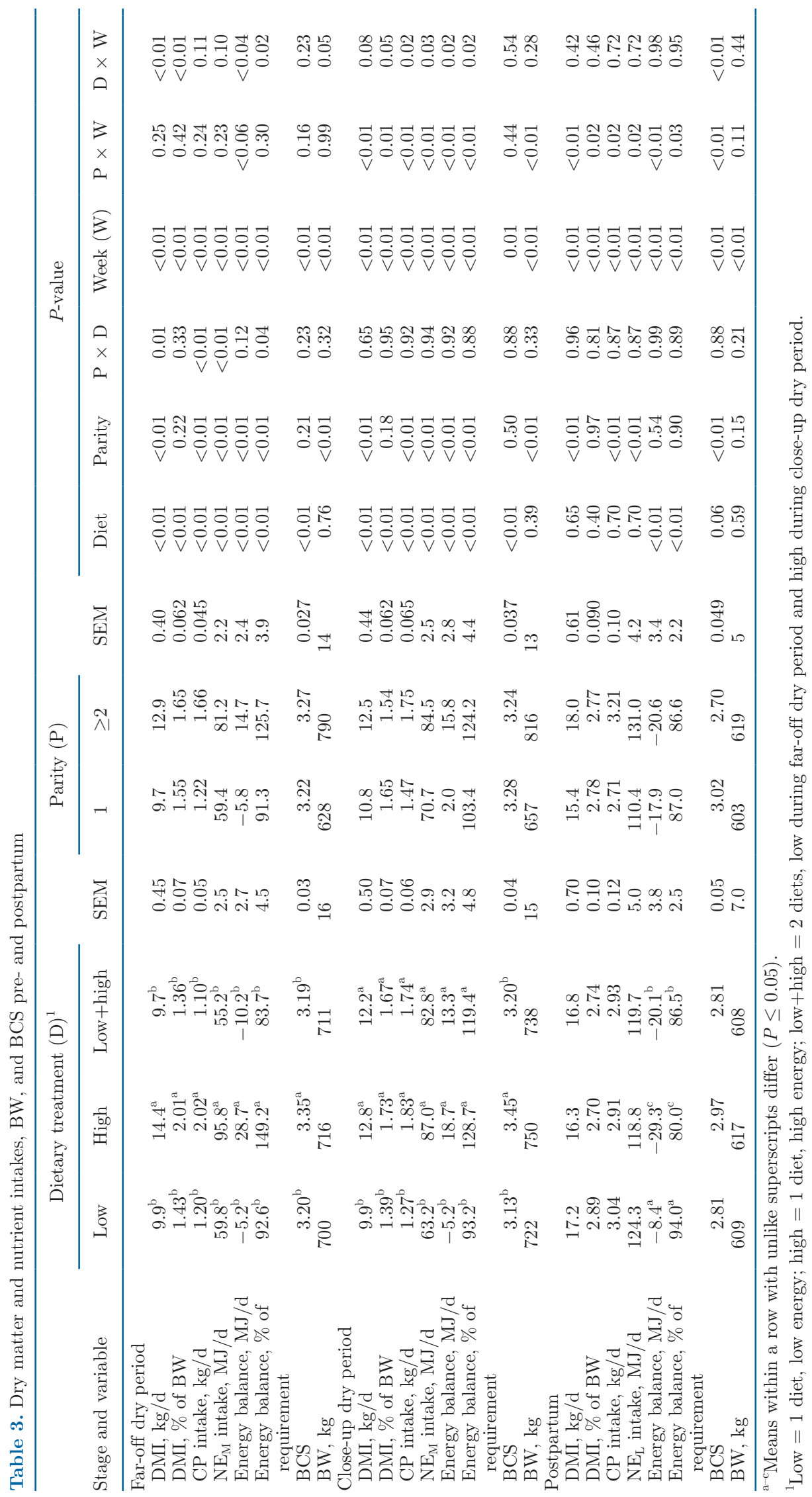


$=0.60)$. In contrast, yield of FCM was greater for $\mathrm{HI}$ cows than for either LO or LO+HI groups $(P=0.03)$, which did not differ from each other (Table 5). The greater FCM yield was mainly driven by differences in milk fat content. Both milk fat content and yield were lower $(P<0.01)$ for LO cows than for HI cows, with LO+HI being intermediate (Table 5). Content $(P=$ $0.34)$ and yield $(P=0.43)$ of true protein in milk were not different among diets (Table 5). Contents of lactose and SNF in milk were lower $(P=0.02)$ for LO than for $\mathrm{HI}$ and $\mathrm{LO}+\mathrm{HI}$ groups (Table 5); however, yields of
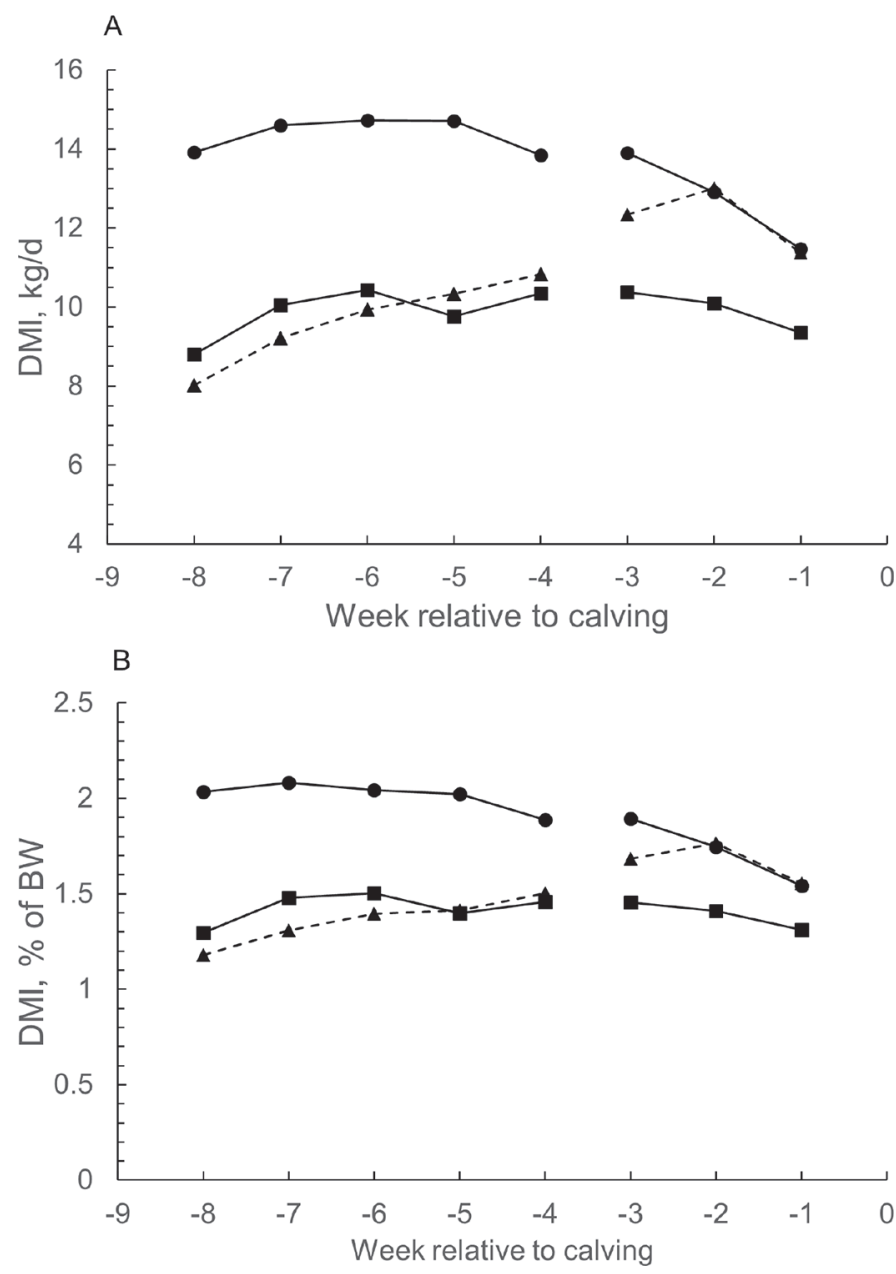

Figure 1. Dry matter intake $(\mathrm{kg} / \mathrm{d}, \mathrm{A}$, and percent of BW, B) for multiparous and primiparous cows fed a low-energy diet for the entire dry period (low, $\mathbf{\square}$ ), a high-energy diet for the entire dry period (high, $\bullet$ ), or the low-energy diet during the far-off dry period and the high-energy diet during the close-up dry period (low+high, $\mathbf{\Delta}$ ). Panel $\mathrm{A}$ : average SEM $=0.54$ (far-off) and 0.57 (close-up). Effects in the far-off model: diet $(P<0.001)$, week $(P<0.001)$, and diet $\times$ week $(P=0.009)$. Effects in the close-up model: $\operatorname{diet}(P<0.001)$, week $(P$ $<0.001)$, and diet $\times$ week $(P=0.08)$. Panel B: average SEM $=0.08$ (far-off) and 0.08 (close-up). Effects in the far-off model: diet $(P<$ $0.001)$, week $(P<0.001)$, and diet $\times$ week $(P=0.004)$. Effects in the close-up model: $\operatorname{diet}(P=0.002)$, week $(P<0.001)$, and $\operatorname{diet} \times$ week $(P=0.05)$.
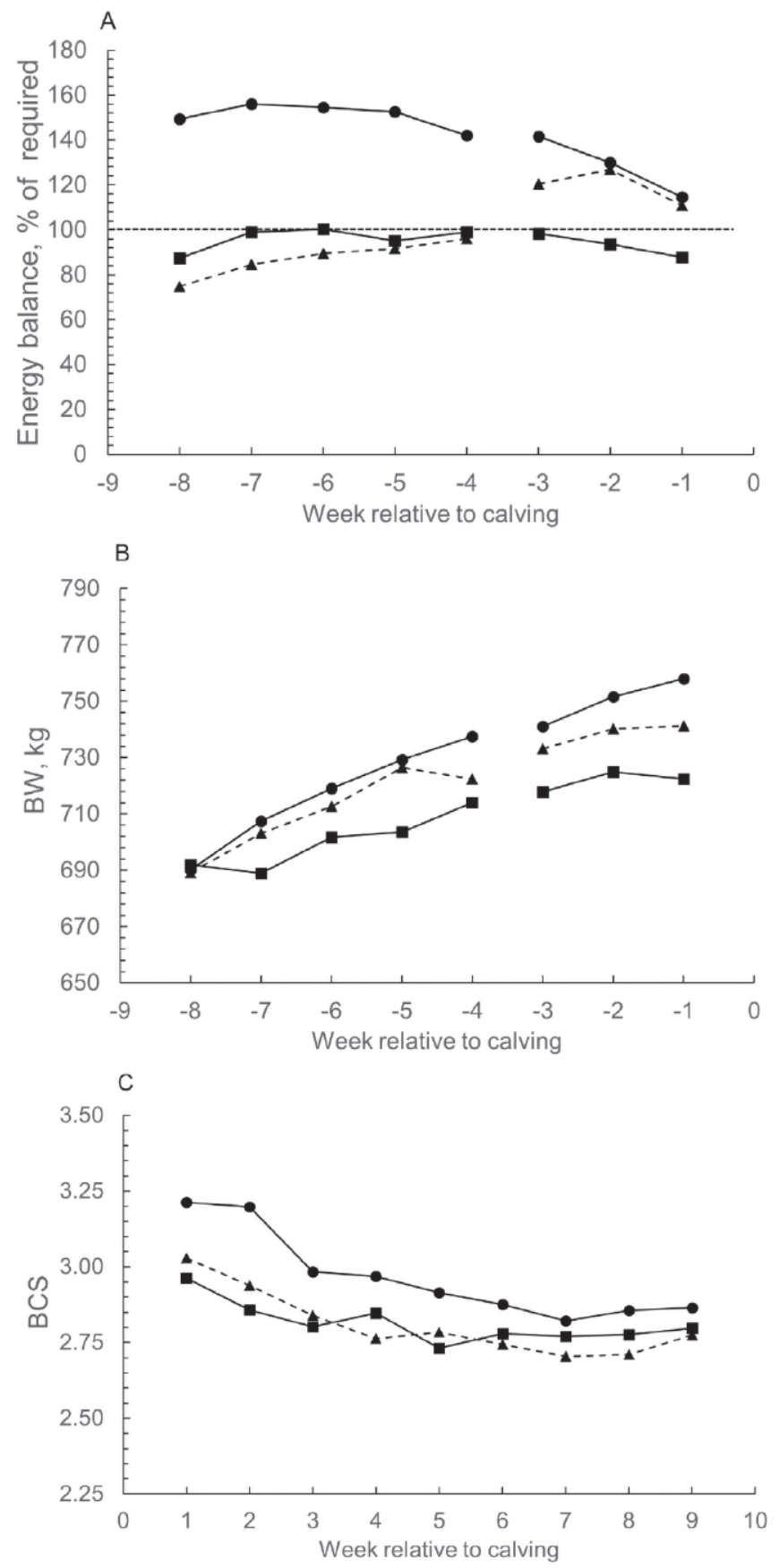

Figure 2. Prepartum energy balance (percent of requirement, A), prepartum weekly mean $\mathrm{BW}(\mathrm{kg}, \mathrm{B})$, and postpartum weekly mean BCS (1 to 5 scale, C) for multiparous and primiparous cows fed a low-energy diet for the entire dry period (low, $\mathbf{0})$, a high-energy diet for the entire dry period (high, $\bullet$ ), or the low-energy diet during the far-off dry period and the high-energy diet during the close-up dry period (low+high, $\mathbf{\Delta}$ ). Panel A: average SEM $=5.4$ (far-off) and 5.6 (close-up). Effects in the far-off model: diet $(P<0.001)$, week $(P<$ $0.001)$, and diet $\times$ week $(P=0.02)$. Effects in the close-up model: diet $(P<0.001)$, week $(P<0.001)$, and diet $\times$ week $(P=0.02)$. Panel B: average SEM $=16.4$ (far-off) and 14.9 (close-up). Effects in the far-off model: $\operatorname{diet}(P=0.76)$, week $(P<0.001)$, and diet $\times$ week $(P=0.06)$. Effects in the close-up model: $\operatorname{diet}(P=0.39)$, week $(P<0.001)$, and diet $\times$ week $(P=0.28)$. Panel C: average SEM $=0.06$. Effects in the model: $\operatorname{diet}(P<0.06)$, week $(P<0.001)$, and diet $\times$ week $(P=0.01)$. 
lactose and SNF were not different among diets (Table $5)$. The calculated efficiency (FCM/DMI) was lowest for $\mathrm{LO}$ and highest for $\mathrm{HI}$, with the $\mathrm{LO}+\mathrm{HI}$ group being intermediate $(P<0.01$; Table 5$)$.

\section{Blood and Liver Components}

During the far-off period, serum NEFA concentration was greater $(P<0.01)$ for $\mathrm{LO}$ and $\mathrm{LO}+\mathrm{HI}$ cows than for HI cows (Table 6), reflecting their lower energy balance compared with HI cows. Concentrations of BHB did not differ $(P=0.22)$ among diets, but serum glucose followed an inverse pattern to NEFA with glucose highest for the HI cows $(P=0.01)$. Urea $\mathrm{N}$ in blood was greater $(P=0.05)$ prepartum for $\mathrm{LO}$ than for $\mathrm{LO}+\mathrm{HI}$ or HI (Table 6). Neither albumin nor cholesterol differed among diets.

During the close-up period, serum NEFA decreased when cows assigned to the $\mathrm{LO}+\mathrm{HI}$ group were switched to the HI diet, such that NEFA were greater $(P<$ 0.01) for $\mathrm{LO}$ than for either $\mathrm{LO}+\mathrm{HI}$ or HI (Table 6). This undoubtedly reflects the large increase in energy balance (Table 3$)$ and the resultant greater $(P=0.02)$ insulin concentration for $\mathrm{LO}+\mathrm{HI}$ and $\mathrm{HI}$ compared with LO (Table 6). Concentration of BHB did not differ among diets (Table 6). Glucose was greater $(P<$ $0.01)$ for cows fed $\mathrm{HI}$ and $\mathrm{LO}+\mathrm{HI}$ than for those fed LO. Urea $\mathrm{N}$ was greater $(P<0.01)$ for cows fed LO than for those fed HI or LO+HI. Serum albumin did not differ among diets $(P=0.17)$. Serum total cholesterol was greater $(P<0.01)$ for HI than for either LO or $\mathrm{LO}+\mathrm{HI}$.

After parturition, serum NEFA for HI cows went from being lower than LO prepartum to significantly higher than the other 2 diets postpartum (Table 6). In addition, a significant treatment by day interaction (Figure $3 \mathrm{~A}$ ) was observed, demonstrating that the con- centration of NEFA was greater for HI during early postpartum and then decreased but remained greater than LO and LO + HI throughout the study period. Corresponding to these data, the LO cows had lower $(P<0.01)$ serum BHB (Table 6$)$ postpartum than did $\mathrm{HI}$ cows. In addition, concentrations of BHB returned to baseline more quickly (diet by day, $P<0.01$ ) for LO than did those for cows fed the $\mathrm{LO}+\mathrm{HI}$ diet (Figure 3B). Serum BHB remained elevated in HI cows for the duration of the study (Figure 3B).

Serum glucose postpartum (Table 6) did not differ $(P=0.54)$ among diets. The insulin concentration was greater for the $\mathrm{LO}+\mathrm{HI}$ cows than for either $\mathrm{LO}$ or $\mathrm{HI}$ cows, resulting in a lower glucose:insulin ratio for that group. Concentrations of urea N, albumin, and cholesterol did not differ among diets postpartum when all cows were receiving the same diet.

Liver total lipid (Table 6, Figure 4A) and triacylglycerol (Table 6, Figure 4B) concentrations were lower $(P$ $<0.01)$ postpartum for LO cows than for HI cows. For the LO+HI cows, total lipids did not differ from the HI cows; triacylglycerols did not differ from the LO group. Interactions of parity and diet were not significant, indicating that both parity groups responded to diet in the same way.

\section{Health}

The incidence of disease and deaths in our experiment is recorded in Table 7. Dietary treatment trends cannot be considered conclusive because there were not enough cows to reach statistically valid conclusions. Three of the metritis cases, 1 on the $\mathrm{HI}$ and 2 on the $\mathrm{LO}+\mathrm{HI}$ treatment, were in cows that had twins. One cow with a retained placenta on the $\mathrm{LO}+\mathrm{HI}$ treatment had twins. All cows reported as having retained placentas were also reported as having metritis.

Table 4. Calving and colostrum data

\begin{tabular}{|c|c|c|c|c|c|c|c|}
\hline \multirow[b]{2}{*}{ Variable } & \multicolumn{3}{|c|}{ Dietary treatment $(\mathrm{D})^{1}$} & \multirow[b]{2}{*}{ Average SEM } & \multicolumn{3}{|c|}{$P$-value } \\
\hline & Low & High & Low +high & & Diet & Parity (P) & $\mathrm{P} \times \mathrm{D}$ \\
\hline $\begin{array}{l}\text { Calf birth weight, }{ }^{2} \mathrm{~kg} \\
\text { Calving difficulty } \\
\text { Colostral IgG, g/L } \\
\text { First colostrum weight },{ }^{4} \mathrm{~kg}\end{array}$ & $\begin{array}{c}42.2 \\
1.54 \\
80.7 \\
4.8\end{array}$ & $\begin{array}{c}40.1 \\
1.64 \\
85.5 \\
6.0\end{array}$ & $\begin{array}{c}40.9 \\
1.78 \\
78.6 \\
5.9\end{array}$ & $\begin{array}{l}1.4 \\
0.26 \\
7.5 \\
1.2\end{array}$ & $\begin{array}{l}0.57 \\
0.83 \\
0.79 \\
0.81\end{array}$ & $\begin{array}{r}<0.01 \\
0.98 \\
0.19 \\
0.02\end{array}$ & $\begin{array}{l}0.69 \\
0.36 \\
0.54 \\
0.51\end{array}$ \\
\hline \multicolumn{8}{|c|}{$\begin{array}{l}{ }^{1} \text { Low }=1 \text { diet, low energy; high }=1 \text { diet, high energy; low }+ \text { high }=2 \text { diets, low during far-off dry period and high during close-up dry period. } \\
{ }^{2} \text { Model included sex }(P<0.05) \text {. } \\
{ }^{3} \text { Scored on a scale of } 1 \text { to } 5 \text {, where } 1=\text { a cow calved between observations without showing signs of parturition, } 2=\text { a cow showed signs of } \\
\text { parturition and calved without assistance in }<6 \mathrm{~h} \text { from first observation, } 3=\mathrm{a} \text { cow was observed for } 6 \mathrm{~h} \text { and the calving progressed naturally } \\
\text { without assistance, } 4=\text { a calving that lasted }>6 \mathrm{~h} \text { and the cow required intervention without the use of mechanical assistance for calving, and } \\
5=\text { a cow required intervention with the use of mechanical extraction. } \\
{ }^{4} \text { Measted }\end{array}$} \\
\hline
\end{tabular}




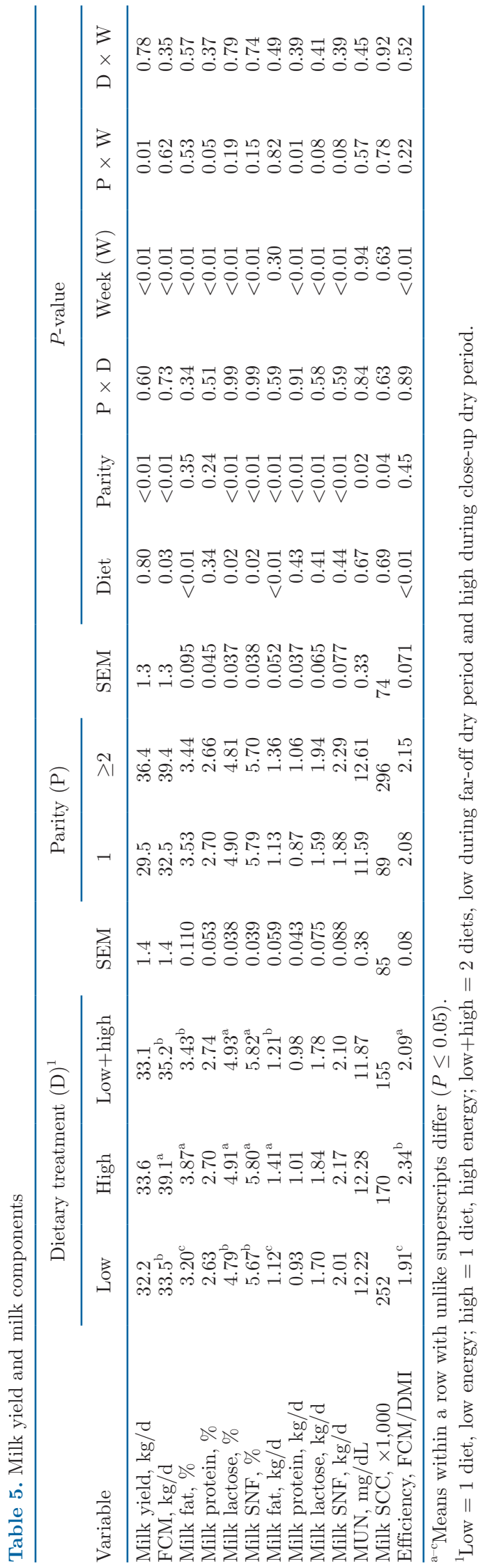

\section{DISCUSSION}

Our major findings from this study were that feeding a higher-energy close-up diet in a 2-diet system had little effect relative to a controlled-energy diet fed throughout the dry period, and that first-calving heifers responded similarly to older cows. Changes during the far-off dry period were as expected given the dietary differences in energy intake, and agree with previous experiments from our group (Dann et al., 2006; Douglas et al., 2006; Janovick and Drackley, 2010) and others (Agenäs et al., 2003; Huang et al., 2014; Mann et al., 2015). The $\mathrm{LO}+\mathrm{HI}$ treatment failed to increase production, indicating that feeding a higher-energy diet before parturition did not increase milk production. We tested the possible consequences of the slightly greater number of lactations and greater previous milk yields for the $\mathrm{LO}+\mathrm{HI}$ cows; however, these factors were not significant when used as covariates in a statistical model in which only multiparous cows were analyzed (data not shown). Feeding the $\mathrm{LO}+\mathrm{HI}$ diet resulted in metabolic responses in blood and liver, including increased serum BHB and increased liver lipid that were intermediate to the LO and HI groups.

Although milk yield did not differ among diets, FCM and milk fat yield were greater for cows fed HI. The greater milk fat production for HI cows likely was attributable to the greater BCS loss after calving. While this would represent a short-term economic benefit, it must be weighed against the greater metabolic risks associated with increased body lipid mobilization.

Our results confirm previous data demonstrating that long-term overfeeding during the dry period increases likelihood of significant lipid deposition in the liver and greater ketogenesis postpartum (Rukkwamsuk et al., 1998; Dann et al., 2006; Janovick et al., 2011), and that controlled-energy diets prevent this hepatic lipid accumulation and ketogenesis (Janovick et al., 2011; Vickers et al., 2013; Huang et al., 2014; Mann et al., 2015). These results support the more negative energy balance, greater milk fat yield, and excessively high calculated efficiency in HI cows compared with the other groups. The generally greater incidence of health problems for HI cows is consistent with results of Janovick et al. (2011), as well as field results reported by Beever (2006) and Colman et al. (2011). Surprisingly, however, our data indicate that even the relatively short (19 d) period of feeding the $\mathrm{HI}$ diet before calving for $\mathrm{LO}+\mathrm{HI}$ cows significantly increased hepatic lipid infiltration and BHB concentrations. Similar responses were observed by Ji et al. (2012) in a more limited number of cows.

The HI cows had significantly increased NEFA and BHB concentrations postpartum despite insulin con- 
Richards et al.: 1-DIET VERSUS 2-DIET SYSTEMS FOR DRY COWS

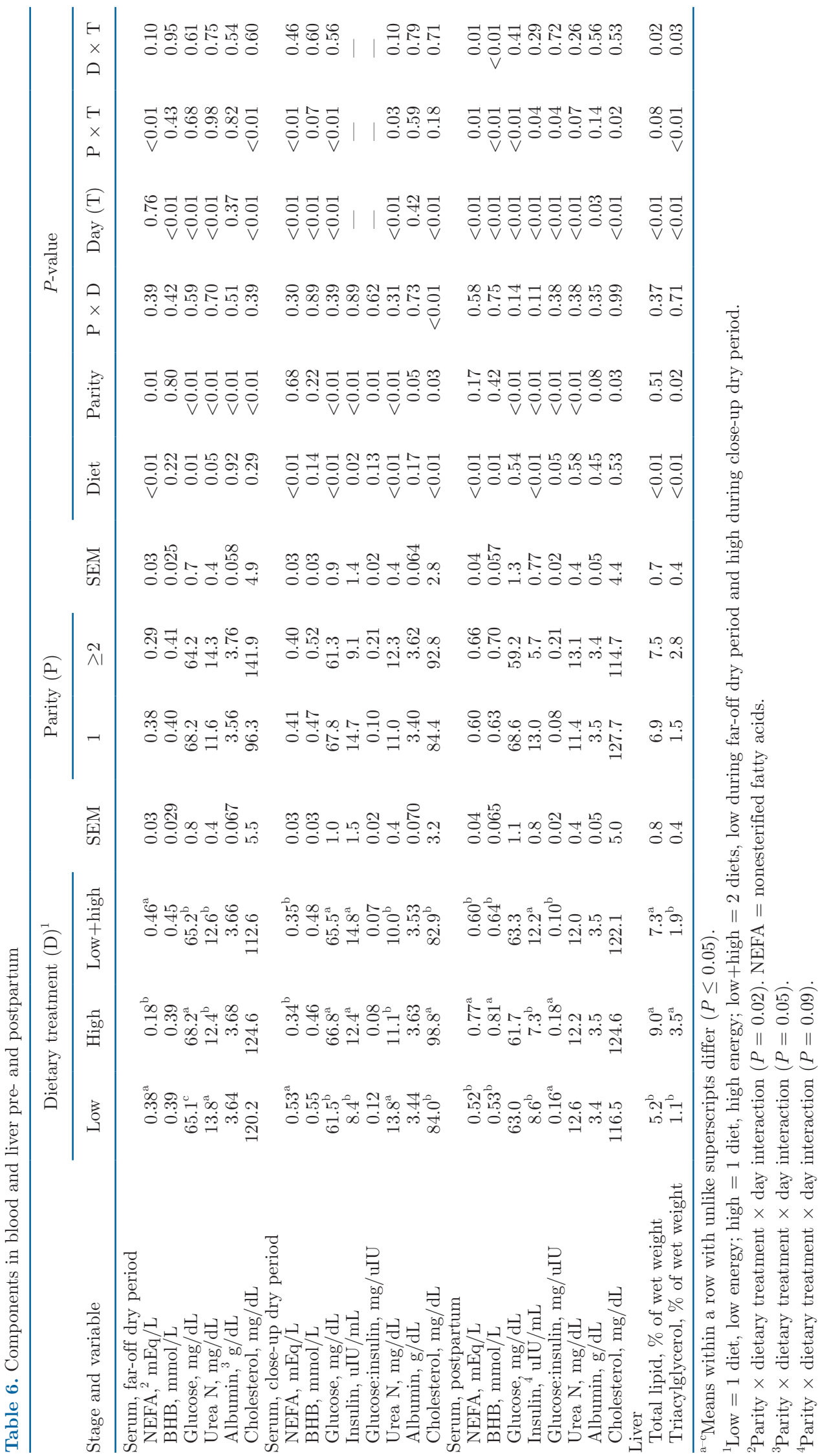


Table 7. Incidence of disease, twins, and deaths

\begin{tabular}{|c|c|c|c|c|c|c|c|c|c|c|}
\hline Parity & $\begin{array}{l}\text { Dietary } \\
\text { treatment }^{1}\end{array}$ & Mastitis & Retained placenta & Metritis & $\mathrm{LDA}^{2}$ & Clinical ketosis & $\begin{array}{c}\text { BHB } \\
>1.4 \mathrm{~m} M\end{array}$ & Milk fever & Twins & Deaths \\
\hline \multirow[t]{2}{*}{1} & High & 0 & 0 & 1 & 0 & 2 & 3 & 0 & 0 & 0 \\
\hline & Low & 0 & 0 & 1 & 1 & 0 & 3 & 0 & 1 & 1 \\
\hline \multirow{3}{*}{$\geq 2$} & High & 1 & 3 & 6 & 2 & 2 & 9 & 1 & 1 & 3 \\
\hline & Low & 3 & 3 & 5 & 1 & 3 & 5 & 0 & 2 & 1 \\
\hline & Low+high & 3 & 2 & 3 & 3 & 3 & 7 & 0 & 3 & 2 \\
\hline All & Low+high & 3 & 2 & 3 & 3 & 3 & 8 & 0 & 4 & 2 \\
\hline
\end{tabular}

${ }^{1}$ Low $=1$ diet, low energy; high $=1$ diet, high energy; low + high $=2$ diets, low during far-off dry period and high during close-up dry period. ${ }^{2} \mathrm{LDA}=$ left displaced abomasum.
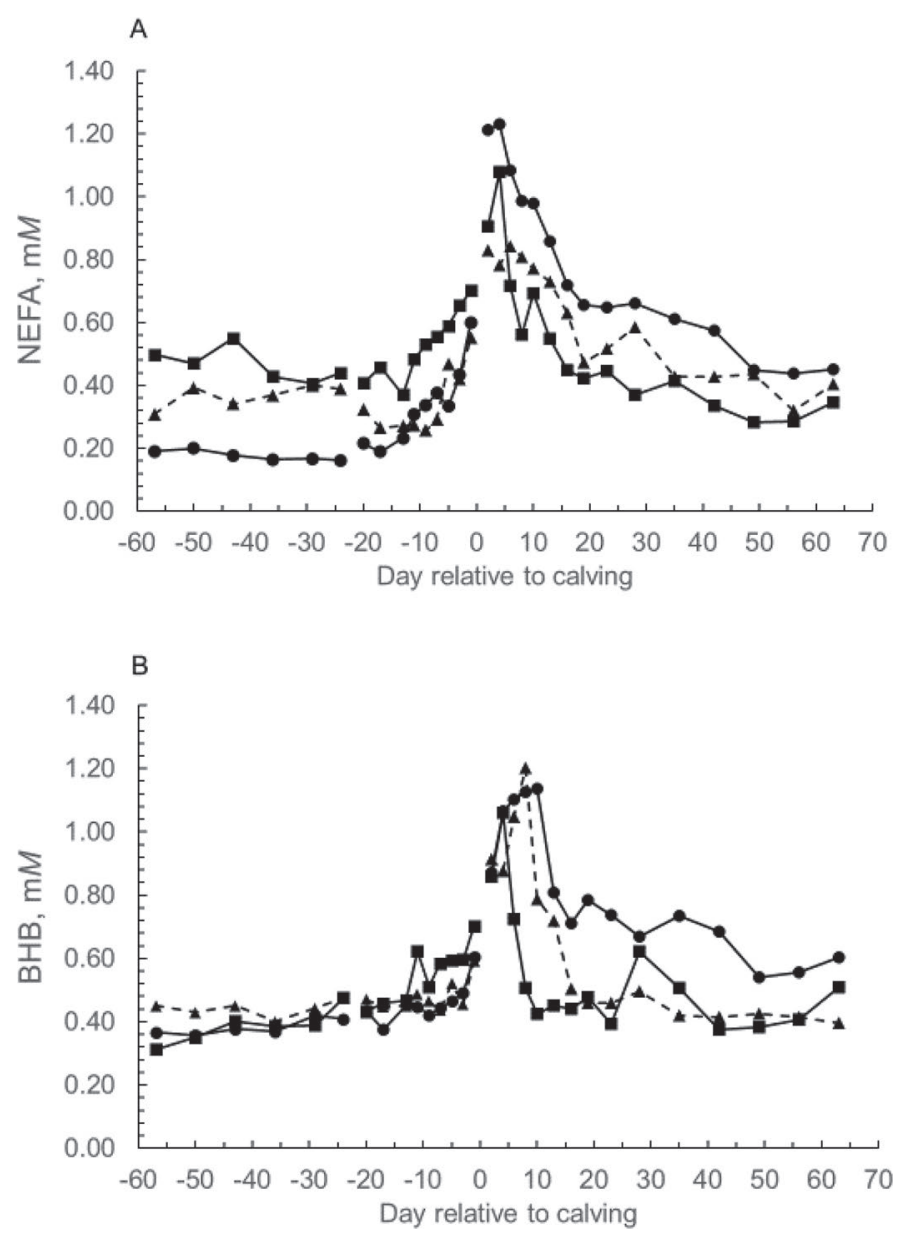

Figure 3. Serum nonesterified fatty acid (NEFA) concentrations (mmol/L, A) and serum BHB concentrations (mmol/L, B) for multiparous and primiparous cows fed a low-energy diet for the entire dry period (low, $\mathbf{0})$, a high-energy diet for the entire dry period (high, -), or the low-energy diet during the far-off dry period and the highenergy diet during the close-up dry period (low+high, $\mathbf{\Delta}$ ). Panel A: average SEM $=0.07$. Effects in the model: $\operatorname{diet}(P<0.01)$, week $(P$ $<0.001)$, and diet $\times$ week $(P=0.01)$. Panel B: average SEM $=0.10$. Effects in the model: $\operatorname{diet}(P=0.01)$, week $(P<0.001)$, and $\operatorname{diet} \times$ week $(P<0.01)$.
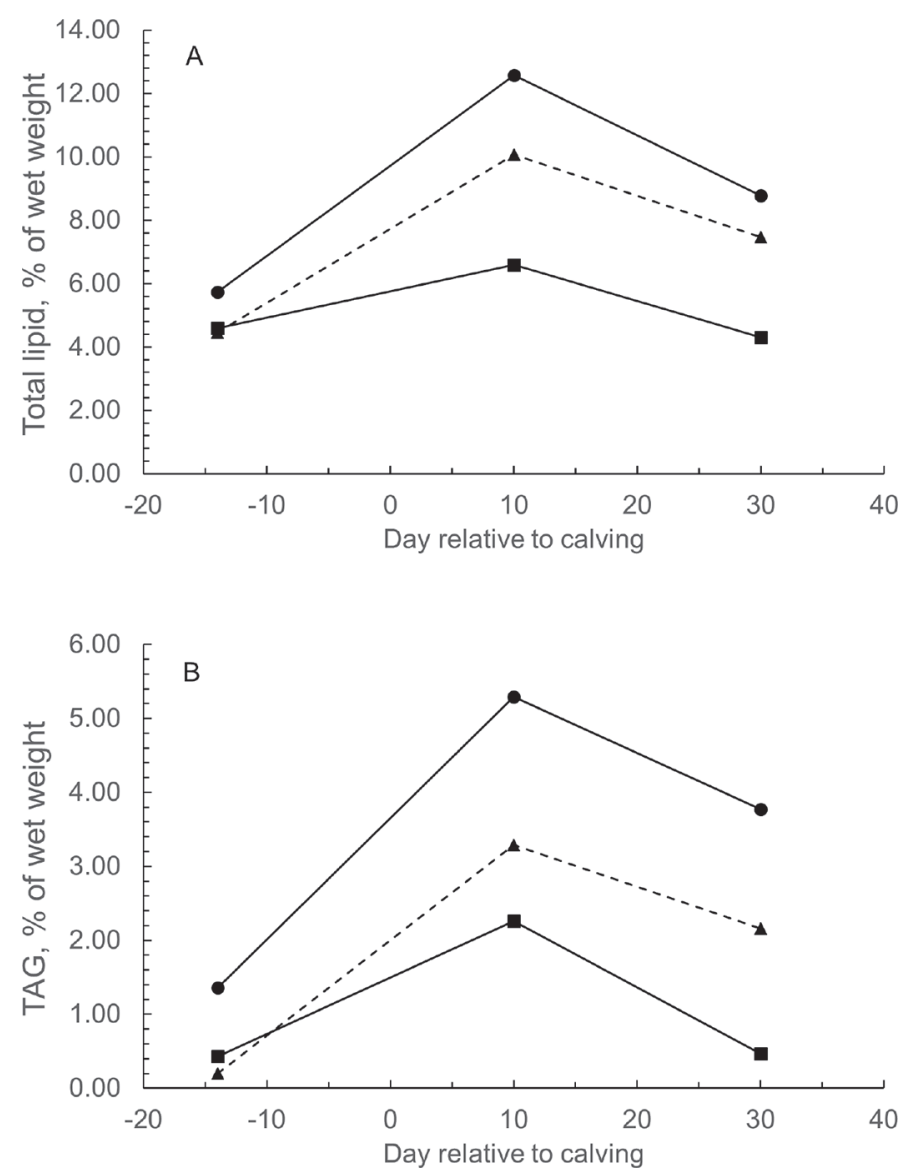

Figure 4. Total lipid concentrations (percent of wet tissue weight, A) and triacylglycerol (TAG) concentrations (percent of wet tissue weight, B) in liver tissue for multiparous and primiparous cows fed a low-energy diet for the entire dry period (low, $\mathbf{0})$, a high-energy diet for the entire dry period (high, $\mathbf{0}$ ), or the low-energy diet during the far-off dry period and the high-energy diet during the close-up dry period (low + high, $\mathbf{\Delta})$. Panel A: average $\mathrm{SEM}=1.0$. Effects in model: $\operatorname{diet}(P=0.004)$, day $(P<0.001)$, and diet by day $(P=0.02)$. Panel B: average SEM $=0.6$. Effects in model: $\operatorname{diet}(P=0.001)$, day $(P<$ $0.001)$, and diet by day $(P=0.03)$. 
centrations and glucose:insulin ratios similar to the $\mathrm{LO}$ cows. In $\mathrm{LO}+\mathrm{HI}$ cows, although nonsignificant, postpartal NEFA and BHB were intermediate to those of LO and HI cows, whereas insulin was significantly greater than either group. These results raise the possibility that overfeeding prepartum affects the ability of insulin to regulate lipolysis and lipid mobilization postpartum. Glucose tolerance tests have provided additional evidence for alterations in insulin activity (Holtenius et al., 2003; Schoenberg and Overton, 2011; Mann et al., 2016a). In contrast, Ji et al. (2012) and Mann et al. (2016c) presented evidence that insulin signaling in adipose tissue relative to glucose homeostasis was not altered by overfeeding. Indeed, Schoenberg et al. (2012) used a hyperinsulinemic, euglycemic clamp study to show that insulin action was not impaired in overfed dry cows. Ji et al. (2012) reported changes in mRNA abundance in adipose tissue that would indicate enhanced lipolysis and NEFA release during even a short period of overfeeding during the late dry period, which would be consistent with results of the present study. The explanation for the increased NEFA and BHB postpartum in overfed cows remains unclear (see discussion in Mann et al., 2016c), but may be related simply to lower DMI and energy balance early postpartum, which subsequently decreases insulin secretion and thereby allows greater NEFA mobilization (Mann et al., 2016c).

The rapid increase in DMI when $\mathrm{LO}+\mathrm{HI}$ cows were switched to the HI diet resulted in those cows rising to DMI similar to the HI cows but then following them downward toward parturition. Similar results were observed by Mann et al. (2015). The initial DMI increase likely reflects responses to the lower dietary NDF of the HI diet and maintenance of rumen fill, whereas chemostatic or hormonal regulatory factors may have decreased intake as calving approached for both $\mathrm{LO}+\mathrm{HI}$ and HI (Allen, 2000). The marked change in DMI and energy balance, with corresponding increases in insulin and decreased NEFA when the $\mathrm{LO}+\mathrm{HI}$ cows were switched to the higher-energy diet were not maintained past the first week postpartum. However, although it appears that a 3 -wk period of close-up feeding is not advantageous and might even be negative, the potential benefits of a short (7 to $10 \mathrm{~d}$ ) "close-up" feeding period are intriguing and should be investigated in future research. We acknowledge that such a practice would be difficult to implement in group housing situations, unless cows were moved to maternity pens at 7 to $10 \mathrm{~d}$ before calving.

Concerns have been expressed about possible differences in calf birth BW and colostrum synthesis when lower energy diets are fed for extended times during the dry period. The lack of difference in calf BW argues against any such effects. Likewise, previous studies from our group (Grum et al., 1996; Dann et al., 2006; Douglas et al., 2006; Janovick and Drackley, 2010) and others (Mann et al., 2015) have not shown differences in calf birth BW. However, numerical differences observed in some of those studies indicate that continued efforts to measure and aggregate effects of prepartal plane of nutrition on calf BW are warranted. Likewise, limited data in our study did not show any effects on colostrum volume or quality. In a similar study design, Mann et al. (2016b) also reported no significant effect on colostrum volume. Nevertheless, numerically lower mean values for first colostrum volume in cows fed LO in our study and that by Mann et al. (2016b) suggest that colostral volume should be measured in future studies with the LO strategy in comparison with other dietary regimens.

A limitation of our study is that, other than making diets isonitrogenous, we did not attempt to equalize MP supplies among diets, in contrast to the design employed by Mann et al. (2015). Lower urea N during the far-off period for cows fed $\mathrm{LO}+\mathrm{HI}$ than for $\mathrm{LO}$ is difficult to explain because $\mathrm{LO}$ and $\mathrm{LO}+\mathrm{HI}$ were consuming the same diet. The lower urea $\mathrm{N}$ in blood of primiparous cows in our study might indicate that MP supply was marginal so that catabolism of AA was decreased due to the greater relative protein requirements for heifers. However, concentrations of albumin in blood were in normal ranges in both parity groups and did not differ among diets, which provides evidence that MP supplies were not limiting.

\section{CONCLUSIONS}

Our results confirm the generally favorable metabolic responses in cows fed LO throughout the dry period, compared with $\mathrm{HI}$ and $\mathrm{LO}+\mathrm{HI}$ cows. These results indicate an increase in lipid accumulation in the liver and greater ketogenesis due to body reserve mobilization in HI cows, increasing the likelihood of fatty liver and subsequent disorders and diseases. Controlling the energy intake of cows during the dry period minimizes lipid accumulation and ketogenesis in the liver postpartum. The only major difference in cow performance due to the $\mathrm{HI}$ diet was the increased milk fat production (and thus yield of FCM). Although this would represent a temporary economic benefit, it must be balanced against a significant increase in DMI (and thus feed cost) over the duration of the dry period and greater risk of lipid-associated disorders postpartum. Compared with $\mathrm{LO}$, the $\mathrm{LO}+\mathrm{HI}$ treatment in this study did not appreciably benefit cows in any way except for 
small increases in milk fat. Thus, the additional feed and inconvenience of formulating a separate diet for a separate group would not be justified by significant economic benefit. Indeed, the increased liver fat accumulation and prolonged elevation of BHB postpartum suggests that this approach might actually increase metabolic risk to cows postpartum.

\section{ACKNOWLEDGMENTS}

Funding for this experiment was provided by Richard Keenan and Sons (Borris, Ireland); Vita Plus (Madison, WI); and state and federal funds provided to the Illinois Agricultural Experiment Station (Urbana). The authors have not stated any conflicts of interest.

\section{REFERENCES}

Agenäs, S., E. Burstedt, and K. Holtenius. 2003. Effects of feeding intensity during the dry period. 1. Feed intake, body weight, and milk production. J. Dairy Sci. 86:870-882. https://doi.org/10 .3168/jds.S0022-0302(03)73670-4.

Allen, M. S. 2000. Effects of diet on short-term regulation of feed intake by lactating dairy cattle. J. Dairy Sci. 83:1598-1624. https:// doi.org/10.3168/jds.S0022-0302(00)75030-2.

Beever, D. E. 2006. The impact of controlled nutrition during the dry period on dairy cow health, fertility and performance. Anim. Reprod. Sci. 96:212-226. https://doi.org/10.1016/j.anireprosci.2006 .08 .002 .

Colman, D. R., D. E. Beever, R. W. Jolly, and J. K. Drackley. 2011. Gaining from technology for improved dairy cow nutrition: Economic, environmental, and animal health benefits. Prof. Anim. Sci. 27:505-517. https://doi.org/10.15232/S1080-7446(15)30532-5.

Dann, H. M., N. B. Litherland, J. P. Underwood, M. Bionaz, A. D'Angelo, J. W. McFadden, and J. K. Drackley. 2006. Diets during far-off and close-up dry periods affect periparturient metabolism and lactation in multiparous cows. J. Dairy Sci. 89:3563-3577. https://doi.org/10.3168/jds.S0022-0302(06)72396-7.

Douglas, G. N., T. R. Overton, H. G. Bateman II, H. M. Dann, and J. K. Drackley. 2006. Prepartal plane of nutrition, regardless of dietary energy source, affects periparturient metabolism and dry matter intake in Holstein cows. J. Dairy Sci. 89:2141-2157. https: //doi.org/10.3168/jds.S0022-0302(06)72285-8.

Doumas, B. T., W. A. Watson, and H. G. Biggs. 1971. Albumin standards and the measurement of serum albumin with bromocresol green. Clin. Chim. Acta 31:87-96. https://doi.org/10.1016/0009 -8981(71)90365-2.

Drackley, J. K., and H. M. Dann. 2008. A scientific approach to feeding dry cows. Chapter 3 in Recent Advances in Animal Nutrition - 2007. P. C. Garnsworthy and J. Wiseman, ed. Nottingham University Press, Nottingham, UK.

Fletcher, M. J. 1968. A colorimetric method for estimating serum triglycerides. Clin. Chim. Acta 22:393-397. https://doi.org/10.1016/ 0009-8981(68)90041-7.

Foster, L. B., and R. T. Dunn. 1973. Stable reagents for determination of serum triglycerides by a colorimetric Hantzsch condensation method. Clin. Chem. 19:338-340. https://doi.org/10.1093/ clinchem/19.3.338.

Grum, D. E., J. K. Drackley, R. S. Younker, D. W. LaCount, and J. J. Veenhuizen. 1996. Nutrition during the dry period and hepatic lipid metabolism of periparturient dairy cows. J. Dairy Sci. 79:18501864. https://doi.org/10.3168/jds.S0022-0302(96)76553-0.
Hara, A., and N. S. Radin. 1978. Lipid extraction of tissue with a low-toxicity solvent. Anal. Biochem. 90:420-426. https://doi.org/ 10.1016/0003-2697(78)90046-5.

Hatcher, L., and E. J. Stepanski. 1994. A Step-by-Step Approach to Using the SAS System for Univariate and Multivariate Statistics. SAS Institute Inc., Cary, NC.

Holtenius, K., S. Agenas, C. Delavaud, and Y. Chilliard. 2003. Effects of feeding intensity during the dry period. 2. Metabolic and hormonal responses. J. Dairy Sci. 86:883-891. https://doi.org/10 .3168/jds.S0022-0302(03)73671-6.

Huang, W., Y. Tian, Y. Wang, A. Simayi, A. Yasheng, Z. Wu, S. Li, and Z. Cao. 2014. Effect of reduced energy density of close-up diets on dry matter intake, lactation performance and energy balance in multiparous Holstein cows. J. Anim. Sci. Biotechnol. 5:30-38. https://doi.org/10.1186/2049-1891-5-30.

Hughes, J. P. 1962. A simplified instrument for obtaining liver biopsies in cattle. Am. J. Vet. Res. 23:1111-1113.

Janovick, N. A., Y. R. Boisclair, and J. K. Drackley. 2011. Prepartum dietary energy intake affects metabolism and health during the periparturient period in primiparous and multiparous Holstein cows. J. Dairy Sci. 94:1385-1400. https://doi.org/10.3168/jds.2010 -3303 .

Janovick, N. A., and J. K. Drackley. 2010. Prepartum dietary management of energy intake affects postpartum intake and lactation performance by primiparous and multiparous Holstein cows. J. Dairy Sci. 93:3086-3102. https://doi.org/10.3168/jds.2009-2656.

Ji, P., J. S. Osorio, J. K. Drackley, and J. J. Loor. 2012. Overfeeding a moderate energy diet prepartum does not impair bovine subcutaneous adipose tissue insulin signal transduction and induces marked changes in peripartal gene network expression. J. Dairy Sci. 95:4333-4351. https://doi.org/10.3168/jds.2011-5079.

Johnson, M. M., and J. P. Peters. 1993. Technical note: An improved method to quantify nonesterified fatty acids in bovine plasma. J. Anim. Sci. 71:753-756. https://doi.org/10.2527/1993.713753x.

Mann, S., F. A. Leal Yepes, M. Duplessis, J. J. Wakshlag, T. R. Overton, B. P. Cummings, and D. V. Nydam. 2016a. Dry period plane of energy: Effects on glucose tolerance in transition dairy cows. J. Dairy Sci. 99:701-717. https://doi.org/10.3168/jds.2015-9908.

Mann, S., F. A. Leal Yepes, T. R. Overton, A. L. Lock, S. V. Lamb, J. J. Wakshlag, and D. V. Nydam. 2016b. Effect of dry period dietary energy level in dairy cattle on volume, concentration of immunoglobulin G, insulin, and fatty acid composition of colostrum. J. Dairy Sci. 99:1515-1526. https://doi.org/10.3168/jds.2015-9926.

Mann, S., F. A. Leal Yepes, T. R. Overton, J. J. Wakshlag, A. L. Lock, C. M. Ryan, and D. V. Nydam. 2015. Dry period plane of energy: Effects on feed intake, energy balance, milk production, and composition in transition dairy cows. J. Dairy Sci. 98:3366-3382. https://doi.org/10.3168/jds.2014-9024.

Mann, S., D. V. Nydam, A. Abuelo, F. A. Leal Yepes, T. R. Overton, and J. J. Wakshlag. 2016c. Insulin signaling, inflammation, and lipolysis in subcutaneous adipose tissue of transition dairy cows either overfed energy during the prepartum period or fed a controlled-energy diet. J. Dairy Sci. 99:6737-6752. https://doi.org/10 .3168/jds.2016-10969.

NRC. 2001. Nutrient Requirements of Dairy Cattle. 7th rev. ed. National Academy Press, Washington, DC.

Peterson, J. I., and D. S. Young. 1968. Evaluation of the hexokinase/ glucose-6-phosphate dehydrogenase method of determination of glucose in urine. Anal. Biochem. 23:301-316. https://doi.org/10 .1016/0003-2697(68)90361-8.

Rukkwamsuk, T., T. Wensing, and M. J. Geelen. 1998. Effect of overfeeding during the dry period on regulation of adipose tissue metabolism in dairy cows during the periparturient period. J. Dairy Sci. 81:2904-2911. https://doi.org/10.3168/jds.S0022 $-0302(98) 75851-5$.

Schoenberg, K. M., R. M. Ehrhardt, and T. R. Overton. 2012. Effects of plane of nutrition and feed deprivation on insulin responses in dairy cattle during late gestation. J. Dairy Sci. 95:670-682. https: //doi.org/10.3168/jds.2011-4529. 
Schoenberg, K. M., and T. R. Overton. 2011. Effects of plane of nutrition and 2,4-thiazolidinedione on insulin responses and adipose tissue gene expression in dairy cattle during late gestation. J. Dairy Sci. 94:6021-6035. https://doi.org/10.3168/jds.2011-4533.

Studer, V. A., R. R. Grummer, S. J. Bertics, and C. K. Reynolds. 1993. Effect of prepartum propylene glycol administration on periparturient fatty liver in dairy cows. J. Dairy Sci. 76:2931-2939. https://doi.org/10.3168/jds.S0022-0302(93)77633-X.

Vandehaar, M. J., G. Yousif, B. K. Sharma, T. H. Herdt, R. S. Emery, M. S. Allen, and J. S. Liesman. 1999. Effect of energy and protein density of prepartum diets on fat and protein metabolism of dairy cattle in the periparturient period. J. Dairy Sci. 82:1282-1295. https://doi.org/10.3168/jds.S0022-0302(99)75351-8.

Vickers, L. A., D. M. Weary, D. M. Veira, and M. A. G. von Keyserlingk. 2013. Feeding a higher forage diet prepartum decreases incidences of subclinical ketosis in transition dairy cows. J. Anim. Sci. 91:886-894. https://doi.org/10.2527/jas.2011-4349.

Williamson, D. H., and J. Mellanby. 1974. D-3-Hydroxybutyrate. Page 1836 in Methods of Enzymatic Analysis. H. U. Bergmeyer, ed. Academic Press, London, UK.

\section{ORCIDS}

B. F. Richards (ํ) https://orcid.org/0000-0002-7090-6479

K. M. Moyes (๑) https://orcid.org/0000-0003-3591-3849

J. K. Drackley @ https://orcid.org/0000-0002-4560-5594 